\title{
INSTITUTIONS AND FIRMS' PERFORMANCE IN TRANSITION COUNTRIES: THE CASE OF SELECTED CESEE COUNTRIES
}

Zoran Aralica, Tonci Svilokos, Katarina Bacic

\section{Abstract}

Institutional reforms in the countries of Central Eastern and South Eastern Europe (CESEE) brought about a redefinition of the role of the state, the market and the business sector. We assess the effects of various dimensions of the institutional environment on the labour productivity of manufacturing firms in selected CESEE countries by employing a multilevel model. Our findings reveal that the curbing of corruption and the provision of inter-industrial externalities through the development of a commercial and professional infrastructure have beneficial effects on firm productivity. At the same time, a stricter political and legal framework and the provision of R\&D infrastructure have an adverse effect. Such a finding is typical for producers of standardised products in countries with low levels of legal framework development for which R\&D and legal adjustments incur cost disadvantages. The implication is that institutional development should be accompanied by a strengthening of firms' absorptive capacity in order for businesses to benefit from such changes.

Keywords: Transition, CESEE countries, Multilevel model, Firms' productivity

JEL Classification: D02, L25, F55

\section{INTRODUCTION}

In the early period of transition among Central Eastern and South-Eastern European (CESEE) countries, i.e. in the early 1990s, there was a commonly accepted position that transition from a centrally planned economy towards a market economy occurs automatically. The role of institutions was, from this point of view, largely neglected 1 . This approach greatly changed over the next two decades, particularly so in the light of European Union enlargement. Today, the economic policies in CESEE countries emphasise the need for governments to create measures to provide impetus for particular types of economic activities. Company performance observed through productivity is one of the aspects where the role of the government was found to be important, specifically in designing policy instruments and policy programmes aimed at increasing company efficiency and in raising
Zoran Aralica, $\mathrm{PhD}$

Senior Research Fellow

The Institute of Economics, Zagreb

E-mail: zaralica@eizg.hr

Tonci Svilokos, PhD

Assistant Professor

Department of Economics and Business Economics University of Dubrovnik

E-mail: tonci.svilokos@unidu.hr

Katarina Bacic, PhD

Indepedent Researcher

E-mail: bacic.keti@gmail.com 
national competitiveness.

Many researchers have explored more deeply the various topics related to the functioning of institutions in CEESE transition countries. Topics such as the influence of institutions on economic growth (e.g. Redek and Sušjan 2005) as well as the influence of institutional effects on economic performance (Efendic and Pugh 2015) in transition economies have been examined. At the same time, literature has appeared on entrepreneurship and the influence of the institutional framework in transition economies (e.g. Estrin and Mickiewicz 2011; Mair and Marti 2009).

Institutional change in these economies was accompanied by the restructuring and privatisation of firms. Initially, firms in transitional economies were found inefficient (Commander and Svejnar 2011), i.e. lagging behind their EU counterparts. The answer was seen in restructuring, where the objective was to increase efficiency. The processes of restructuring and privatisation were carried out faster in CEE countries than in SEE countries. This policy approach led to the stronger participation of foreign investment enterprises in CEE countries that consequently had stronger effects on firm performance. However, a common feature of both groups of countries is that the process of institution building had been slow, and it was this process that was expected to facilitate transition to a market economy and have a positive effect on firm performance. Furthermore, when institutional efficiency in facilitating knowledge creation and diffusion at the level of the firm is examined, CESEE countries lag behind the Western European economies, as is evident from the European Innovation Scoreboard - EIS (2017) indicators ${ }^{2}$.

The influence of institutions on firm performance has been recognised among various research perspectives: in the literature related to technological upgrading and economic development (e.g. Goedhuys and Srholec 2015), in the literature on the institutionbased view (Ngo et al. 2016), as well as in the literature dealing with how the institutional environment influences the development of entrepreneurship (e.g. Estrin and Mickiewicz 2011; Williams and Vorley 2015). For example, using multilevel modeling for Asian and Latin American developing countries, research reveals that national institutions influence firms' total factor productivity (TFP) (Goedhuys and Srholec 2015). However, research that analyses the direct influence of institutions on productivity at the country level in CESEE countries has so far been scarce. The research presented in this paper fills this gap and extends the literature by examining the importance of the quality of governance and the institutional setting for firm performance.
We assess the influence of formal institutions on productivity which is a key measure of the performance of manufacturing firms within the selected CESEE countries. The institutional variables are modelled as control variables. The main advantage of this approach lies in the fact that the influence of various types of institutions on industrial production at the level of the manufacturing firm can be examined for the selected countries. The countries include: Slovenia and Croatia (CEE countries) and Bosnia and Herzegovina (B\&H), Serbia, Montenegro and the former Yugoslav Republic of Macedonia (the FYR of Macedonia) (SEE countries).

Compared to the previous studies, the main advantage of this paper is that we provide more explicit institutional measurements and investigate national institutional dimensions and differences among the selected countries. We approach this issue by exploiting selected dimensions of the WGI index separately to gain more precise insight into the influence of these institutional conditions. This is because one different dimension can have counter effects or even remain neutral.

The results of this research can be put to use to provide institution/policy related recommendations, in particular how the activities/dimensions which result from the research can encourage the development of industrial production and increase productivity in the selected group of countries.

The paper is organised as follows. First, a brief literature review is provided, analysing the relation between institutions and firm performance. The next section presents a comparative analysis of institutions among the selected countries followed by model specifications and results. Concluding remarks are presented in the last section.

\section{LITERATURE REVIEW}

In the last three decades, there has been considerable research that has found the direct influence of institutions on economic growth and development (e.g. Vijayaraghavan and Ward 2001; Rodrik, Subramanian, and Trebbi 2004; Beck and Laeven 2006), based on the propositions from the literature on economic growth. Another stream of literature has analysed the influence of institutions on economic performance by examining direct effects (Efendic and Pugh, 2015) and indirect effects that occur through different channels: domestic private and foreign investment (Dang 2009), trade (Rodrik, Subramanian, and Trebbi 2004), the stock of human and social capital (Raiser 1999; Dias, Tebaldi 2012; Bartlett et al. 2013; Acemoglu Gallego, 
and Robinson 2014), political instability, managing conflicts and other policies. The research in its analysis usually chooses one of the following three approaches: cross-sectional country analysis (Dollar and Kraay 2003; Beck and Laeven 2006; Rodrik, Subramanian, and Trebbi 2004), panel data analysis (Vijayaraghavan and Ward 2001; Talbott and Roll 2001; Bartlett et. al. 2013), and country case studies (Lanjouw and Levy 2002; Atieno 2001; Nakabashi, Gonçalves Pereira, and Sachsida 2013).

As research methods are becoming more complex, firm performance is currently most often observed via indicators such as total factor productivity (Goedhuys and Srholec 2015) that represents a microeconomic measure of efficiency. The institutional environment partly constitutes the business environment in which the firms operate, and appears as a relevant determinant of firm performance. When defined as a variable in a model, it may include political factors (e.g. government expenditure (Kaufmann, Kraay, and Mastruzzi 2010)), legal factors (e.g. the dimensions of regulatory quality, rule of law and control of corruption of the Worldwide Governance Indicators) and economic factors (e.g. GDP, and/or rate of unemployment (Olbrecht 2016, p. 2088)).

A variety of indicators which describe various formal institutions and the availability of internationally comparative datasets at a micro level (e.g. Bureau van Dijk's Orbis database) have enabled researchers in the last few years to pursue more complex analysis that cuts across micro- and macro-economics.

One strand of research belongs to the literature related to economic development and catching up. Within this literature, the importance of knowledge and its spill-overs among various institutions/organisations is emphasised. Recognition of the importance of the endogenous growth theory with the presumption of increasing returns driven by knowledge spillovers between firms and other organisations producing knowledge (Romer 1986; Aghion and Howitt 1992) represents the foundation for this direction of research.

In parallel, the power of social variables in the prediction of economic growth (Temple and Johnson 1998) has been recognised. Described as social capabilities $^{3}$ by Abramovitz (1986), in fact they are interactions that include other sets of competences and capabilities within the institutional environment. Following this logic, facilitating efficient use of technology requires various types of organisations and institutions within a specific location whose role in this process is to ensure formal and informal interaction among the relevant agents.
The first empirical contributions (Fagerberg 1987; Verspagen 1991) which follow these ideas were macro studies where the implications for firm performance are implicit. Recently a few empirical papers have been written which emphasise the role of institutions in the productivity of firms. In their analysis, Goedhuys and Srholec (2015) focus on the technological and educational infrastructure and found that these factors have an influence on economic performance. By analysing the impact of institutions on firm performance in EU countries, Olbrecht (2016) found a positive effect of the political and legal framework and openness of the economy on firm performance and a negative impact of government expenditures and macroeconomic indicators. There are two types of studies which can be considered as studies belonging to this group of literature: the first type is related to transition countries where focus is placed on recognising differences among the countries (e.g. Commander and Svejnar 2011) and the second type are innovation studies (e.g. Mohnen, Mairesse, and Dagenais 2006).

The second group of literature analyses the influence of formal and informal institutions on the development of entrepreneurship and the interaction of enterprises with their institutional environment in transition economies (e.g. Mair and Marti 2009; Williams and Vorley 2015). This group concentrates on the development of entrepreneurship within emerging economies and the interaction of enterprises with their institutional environment. By referring to North (1990), Estrin, Korosteleva, and Mickiewicz (2013) state that many of the incentives underlying value-adding behaviour depend on the quality of institutions. This can be considered as the basic idea behind this group of research. Along with research on the direct influence of various institutions on entrepreneurship, research has been conducted on the misalignment between formal and non-formal institutions (e.g. Crafts 2001, p. 356) ${ }^{4}$. The institutional asymmetry between formal and informal institutions is important as it may weaken the development of entrepreneurship, or, in some cases, it might push entrepreneurs into the informal sector (e.g. Williams and Shahid 2016). Importantly, Estrin and Mickiewicz (2011) found lower rates of entrepreneurship within developing market economies compared to developed market economies. These results were explained by the legacy of communist planning, as well as by the slow adoption of informal institutions, e.g. attitudes and social norms in developing economies. Analysing the aspirations for employment growth of entrepreneurs ${ }^{5}$, Estrin, Korosteleva, and Mickiewicz (2013) found the negative impact of higher levels of corruption, weaker property 
rights and greater government activity within the analysed national economies. An interesting study on the aspiration for growth in Bosnia and Herzegovina was provided by Efendic, Mickiewicz, and Rebmann (2015). They argue that in a post-conflict country, ethnic pluralism is indicative of local norms of tolerance towards experimentation and risk-taking which support growth aspirations among entrepreneurs.

In literature focusing on misalignment between formal and informal institutions, Williams and Vorley (2015) analyse how the institutional environment influences the development of entrepreneurship in Bulgaria. Using in-depth interviews with Bulgarian entrepreneurs, the authors found asymmetry between formal and informal institutions as a result of informal institutions that hamper entrepreneurship. Using face-to-face interviews, Williams and Franic (2016) analysed the participation of entrepreneurs in the informal economy in Croatia. They found that participation in the informal economy results from the asymmetry between the norms, values and beliefs of citizens (informal institutions) and codified laws and regulations (formal institutions). Finally, Williams and Vorley (2017) analysed how the institutional environment influences the development of entrepreneurship in Kosovo, a post-conflict environment. They found that the alignment of institutional arrangements defines the extent to which entrepreneurial activity is productive.

The third group of research belongs to an institution-based view of literature. This research takes an institutional perspective in international business research (Nguyen, Le, and Bryant 2013). The main idea of this group of literature is to explain how local institutional factors affect firm performance in emerging markets. This area of research is quite relevant for East Asian economies since these economies have experienced huge institutional change in the last few decades, i.e. in the development of the private sector. These changes make institutions far more relevant in emerging economies than in developed economies (Meyer and Peng 2013). This occurred in parallel with the internationalisation of SME activities in these countries. Ngo et al. (2016) found that domestic institutional specificity - stability, predictability and enforceability - has a positive effect on exporting the good performance of Vietnam firms. Nguyen, Le, and Bryant (2013) analysed the direct influence on firm performance and found a moderate relationship of the firms' export strategy to performance. Furthermore, they argue that government reforms push firms toward developing strategies that are more effective in competing with foreign rivals.

\section{COMPARATIVE ANALYSIS OF INSTITUTIONS AMONG THE SELECTED CESEE COUNTRIES}

\subsection{The sample and data}

The focus of the quantitative research in this paper is on manufacturing firms in five post-transition countries in CESEE countries: Slovenia, Croatia, Bosnia and Herzegovina, Serbia, and the Former Yugoslav Republic of Macedonia (the FYR of Macedonia). The sample includes countries that share a common pretransition economic and political history and are located in a common spatial context. Despite being under the umbrella of a common economic policy in the pre-transition period, these countries were even in those times remarkably divergent in their levels of development. Slovenia and Croatia were more advanced in their development trajectory and this advantage of their starting position has remained unchanged up to the present time. Backed by superior economic performance and their favourable geographical proximity to the European Union (EU), these two countries became EU Member States - Slovenia in 2004, whereas Croatia joined the EU quite a bit later in 2013. Currently, Montenegro, Serbia and the FYR of Macedonia are EU candidate countries, already transforming and adjusting their national legislation to achieve compatibility with the acquis communautaire. Bosnia and Herzegovina and Kosovo are at present potential candidate countries for EU membership. In their international trading, tourism and investments (i.e. firm ownership), these economies are tied and interdependent, to a greater or lesser extent. Thus, despite some divergence in the level of development, these economies make an interesting case for observing macroeconomic effects and the effects of institutional quality/quality of governance on the performance of manufacturing firms. Miščević and Mrak $(2017$, p. 192) consider these countries, apart from Croatia and Slovenia, to be institutionally weak. They argue that growing legal uncertainty, corruption and increasing poverty in these countries affect the EU's public perception of them. The main result is skepticism within EU decision-making mechanisms towards EU enlargement in the Western Balkans region.

Considering that institutions in a narrow sense can be considered "laws" and in a wider sense "culture" (Mitra, Muravyev, and Schaffer 2008), even the mentioned national legal adjustments to EU legislation are expected to contribute to changes in the quality of overall governance, while the most important factors are comprehensive reforms. A wide array of indicators/indices based on national data that capture the quality of governance/institutions on a comparable basis are being constructed by reputable international 
organisations.

Considering the research intention of this paper, data drawn from various levels of the economy and policy are required. First, microeconomic data are drawn from Bureau van Dijk's Orbis database on firms that allow international comparison and is widely used in economic research. Roughly $99 \%$ of 275 million companies in the database are private. The Orbis database offers the use of data on over 129,000 manufacturing firms in all manufacturing branches from the observed economies. The period under observation is from 2010 to 2015. Importantly, the database offers value-added series and financial and economic data that are essential in productivity modeling, as it contains profit and loss account data and data from the balance sheets. Furthermore, the database contains information on corporate ownership structures, including foreign ownership, data on firm location, the date of incorporation, and on NACE - a series also found relevant in the context of this research.

The data on quality of governance and the institutional setting are drawn from the Worldwide Governance Indicators (WGI) issued by the World Bank and the Global Entrepreneurship Monitor survey. WGI aggregate indicators are constructed over six dimensions of governance based on the governance perception of enterprise, citizen and expert survey respondents across countries (WB 2017). For the purpose of this research, five of the dimensions are considered relevant: political stability and absence of violence/ terrorism, government effectiveness, regulatory quality, rule of law and control of corruption.

Political stability and absence of violence/terrorism capture perceptions of the likelihood that the government will be destabilised or overthrown by unconstitutional or violent means. Government effectiveness measures the perceptions of the quality of public services, the quality of the civil service and the degree of its independence from political pressures. Regulatory quality represents the perceptions of the ability of the government to formulate and implement sound policies and regulations that permit and promote the development of the private sector. Rule of law capture perceptions of the extent to which agents have confidence in and abide by the rules of society, and in particular the quality of contract enforcement, property rights, the police, and the courts. Control of corruption shows perceptions of the extent to which public power is exercised for private gain. Further explanation of the aggregate indicators is provided in Kaufmann, Kraay, and Mastruzzi (2010, p. 4).

While there is criticism of the WGI approach and perception-based indicators in general, Kaufmann, Kraay, and Mastruzzi (2010) provide strong arguments about why data on perceptions provide more value to the measurement of governance. Agents, including enterprises, make decisions (such as investment decisions or decisions to use a public service) based upon their perception of various aspects of the quality of governance (e.g. the investment climate and the quality of public services). Some aspects of governance cannot be captured in any other way than by perception, the level of corruption being the obvious case here. Furthermore, in the confrontation of objective and subjective measures, these authors note that reality is often better reflected through subjective measures, often where there are differences in formally envisaged procedures and legal acts (as objective measures) that do not correspond to the usual practice (viewed as reality through subjective measures).

It might be expected that the development of the commercial and professional infrastructure, as well as the physical and services infrastructure, influences firm performance. The commercial and professional infrastructure includes the presence of property rights, commercial, accounting and other legal and assessment services, and institutions that support or promote SMEs. The physical and services infrastructure represents how difficult it is to access physical resources, communication, utilities, transportation, land or space at a price that does not discriminate against SMEs.

\subsection{Descriptive analysis}

Different dimensions of the entrepreneurial framework, including institutional aspects, are captured by the Global Entrepreneurship Monitor (GEM) and by the World Bank Worldwide Governance Indicators. GEM's entrepreneurial ecosystem consists of nine dimensions, four of which are shown in Table 1. The quality of these dimensions is assessed through national expert surveys. Across the different dimensions used in this research, satisfaction is strongest for the physical and service infrastructure. This is in line with the general conclusion of GEM at the world level, even in 2016/17 (GEM 2017). Similar variables for estimating the impact of institutions on microenterprises were used in Monteiro and Assuncao (2012), Hu, Jefferson, and Jinchang. (2005) and in Zamberi, Ahmad, and Xavier (2012).

Overall conditions are obviously most satisfying in Slovenia, the first country that became an EU Member State among the analysed countries and the most developed economy. Another relatively better rated feature of the entrepreneurial ecosystem among the observed economies is the commercial 
Table 1: Institutional indicators

\begin{tabular}{|c|c|c|c|c|c|c|c|}
\hline Country - year & $\begin{array}{c}\text { Control of } \\
\text { corrupt. }\end{array}$ & Rule of law & $\begin{array}{c}\text { Regulat. } \\
\text { quality }\end{array}$ & $\begin{array}{l}\text { Taxes and } \\
\text { bureaucr. }\end{array}$ & $\begin{array}{c}\text { R\&D } \\
\text { transfer }\end{array}$ & $\begin{array}{l}\text { Physical } \\
\text { and service } \\
\text { infrastruct. }\end{array}$ & $\begin{array}{c}\text { Commercial } \\
\text { and prof. } \\
\text { infrastruct. }\end{array}$ \\
\hline $\mathrm{B} \& \mathrm{H}-07$ & -0.37 & -0.49 & -0.28 & & & & \\
\hline $\mathrm{B} \& \mathrm{H}-08$ & -0.35 & -0.41 & -0.16 & 1.69 & 1.81 & 3.12 & 2.68 \\
\hline $\mathrm{B} \& \mathrm{H}-09$ & -0.37 & -0.35 & -0.1 & 1.7 & 1.72 & 3.06 & 2.68 \\
\hline $\mathrm{B} \& \mathrm{H}-10$ & -0.32 & -0.37 & -0.1 & 1.81 & 2.09 & 3.27 & 2.82 \\
\hline $\mathrm{B} \& \mathrm{H}-11$ & -0.31 & -0.35 & -0.04 & 1.78 & 2.01 & 3.41 & 2.9 \\
\hline B\&H - 12 & -0.29 & -0.22 & -0.05 & 1.73 & 1.97 & 3.25 & 2.84 \\
\hline B\&H - 13 & -0.22 & -0.15 & -0.07 & 1.8 & 1.89 & 3.32 & 2.71 \\
\hline$B \& H-14$ & -0.28 & -0.2 & -0.09 & 1.74 & 1.96 & 3.35 & 2.92 \\
\hline $\mathrm{B} \& \mathrm{H}-15$ & -0.37 & -0.29 & -0.18 & $\mathrm{n} / \mathrm{a}$ & $\mathrm{n} / \mathrm{a}$ & $\mathrm{n} / \mathrm{a}$ & $\mathrm{n} / \mathrm{a}$ \\
\hline Croatia - 07 & 0.08 & 0.08 & 0.49 & 1.9 & 2.23 & 3.58 & 2.73 \\
\hline Croatia - 08 & -0.04 & 0.08 & 0.51 & 1.88 & 2.2 & 3.77 & 2.74 \\
\hline Croatia - 09 & -0.1 & 0.14 & 0.56 & 1.9 & 2.26 & 3.67 & 2.91 \\
\hline Croatia - 10 & -0.03 & 0.17 & 0.56 & 1.96 & 2.3 & 3.62 & 2.83 \\
\hline Croatia - 11 & 0.01 & 0.18 & 0.52 & 1.84 & 2.25 & 3.65 & 2.84 \\
\hline Croatia - 12 & -0.04 & 0.22 & 0.45 & 1.74 & 2.13 & 3.5 & 2.78 \\
\hline Croatia - 13 & 0.11 & 0.27 & 0.45 & 1.83 & 2.08 & 3.5 & 2.7 \\
\hline Croatia - 14 & 0.19 & 0.31 & 0.4 & 1.55 & 2.04 & 3.67 & 2.9 \\
\hline Croatia - 15 & 0.2 & 0.2 & 0.36 & 1.35 & 1.77 & 3.82 & 2.6 \\
\hline Macedonia - 07 & -0.31 & -0.19 & -0.16 & $\mathrm{n} / \mathrm{a}$ & $\mathrm{n} / \mathrm{a}$ & $\mathrm{n} / \mathrm{a}$ & $n / a$ \\
\hline Macedonia - 08 & -0.19 & -0.07 & -0.12 & 2.47 & 2.01 & 3.41 & 2.94 \\
\hline Macedonia - 09 & -0.16 & 0.07 & -0.04 & $\mathrm{n} / \mathrm{a}$ & $\mathrm{n} / \mathrm{a}$ & $\mathrm{n} / \mathrm{a}$ & $\mathrm{n} / \mathrm{a}$ \\
\hline Macedonia - 10 & -0.24 & 0 & -0.07 & 2.81 & 2.19 & 3.61 & 3.34 \\
\hline Macedonia - 11 & -0.21 & -0.02 & -0.06 & $\mathrm{n} / \mathrm{a}$ & $\mathrm{n} / \mathrm{a}$ & $\mathrm{n} / \mathrm{a}$ & $\mathrm{n} / \mathrm{a}$ \\
\hline Macedonia - 12 & -0.09 & 0 & 0.02 & 3.01 & 2.38 & 3.57 & 3.52 \\
\hline Macedonia - 13 & -0.25 & 0.03 & 0.06 & 2.86 & 2.37 & 3.54 & 3.02 \\
\hline Macedonia - 14 & -0.01 & 0.07 & 0.12 & $\mathrm{n} / \mathrm{a}$ & $\mathrm{n} / \mathrm{a}$ & $\mathrm{n} / \mathrm{a}$ & $\mathrm{n} / \mathrm{a}$ \\
\hline Macedonia - 15 & -0.09 & 0.03 & 0.23 & 2.79 & 2.44 & 3.83 & 3.1 \\
\hline Serbia - 07 & -0.35 & -0.5 & -0.34 & 2.56 & 2.35 & 3.3 & 3.36 \\
\hline Serbia - 08 & -0.3 & -0.53 & -0.29 & 2.39 & 2.24 & 3.01 & 2.82 \\
\hline Serbia - 09 & -0.31 & -0.44 & -0.12 & 1.95 & 2.48 & 2.77 & 3.07 \\
\hline Serbia - 10 & -0.29 & -0.4 & -0.02 & $\mathrm{n} / \mathrm{a}$ & $\mathrm{n} / \mathrm{a}$ & $\mathrm{n} / \mathrm{a}$ & $\mathrm{n} / \mathrm{a}$ \\
\hline Serbia - 11 & -0.25 & -0.32 & 0.03 & $\mathrm{n} / \mathrm{a}$ & $\mathrm{n} / \mathrm{a}$ & $\mathrm{n} / \mathrm{a}$ & $\mathrm{n} / \mathrm{a}$ \\
\hline Serbia - 12 & -0.31 & -0.38 & -0.07 & $\mathrm{n} / \mathrm{a}$ & $\mathrm{n} / \mathrm{a}$ & $\mathrm{n} / \mathrm{a}$ & $\mathrm{n} / \mathrm{a}$ \\
\hline Serbia - 13 & -0.27 & -0.34 & -0.06 & $\mathrm{n} / \mathrm{a}$ & $\mathrm{n} / \mathrm{a}$ & $\mathrm{n} / \mathrm{a}$ & $\mathrm{n} / \mathrm{a}$ \\
\hline Serbia - 14 & -0.19 & -0.16 & 0.14 & $\mathrm{n} / \mathrm{a}$ & $\mathrm{n} / \mathrm{a}$ & $\mathrm{n} / \mathrm{a}$ & $\mathrm{n} / \mathrm{a}$ \\
\hline Serbia - 15 & -0.24 & -0.09 & 0.14 & $\mathrm{n} / \mathrm{a}$ & $\mathrm{n} / \mathrm{a}$ & $\mathrm{n} / \mathrm{a}$ & $\mathrm{n} / \mathrm{a}$ \\
\hline Slovenia - 07 & 0.98 & 0.89 & 0.8 & 2.04 & 2.31 & 3.65 & 3.06 \\
\hline Slovenia - 08 & 0.91 & 0.98 & 0.83 & 2.23 & 2.46 & 3.78 & 3.09 \\
\hline Slovenia - 09 & 1.02 & 1.06 & 0.92 & 2.32 & 2.57 & 3.87 & 3.06 \\
\hline Slovenia - 10 & 0.85 & 0.98 & 0.75 & 2.4 & 2.4 & 3.97 & 3.19 \\
\hline Slovenia - 11 & 0.9 & 1.04 & 0.69 & 2.05 & 2.51 & 3.98 & 2.94 \\
\hline Slovenia - 12 & 0.82 & 0.99 & 0.62 & 2.09 & 2.36 & 3.83 & 2.91 \\
\hline Slovenia - 13 & 0.71 & 0.98 & 0.62 & 2.05 & 2.39 & 3.89 & 2.82 \\
\hline Slovenia - 14 & 0.69 & 0.98 & 0.66 & 1.92 & 2.29 & 3.56 & 2.71 \\
\hline Slovenia - 15 & 0.73 & 0.95 & 0.62 & 1.93 & 2.29 & 3.83 & 2.82 \\
\hline
\end{tabular}

Resources: Global Entrepreneurship Monitor (GEM) and the World Bank Worldwide Governance Indicators 
and professional infrastructure. Public policy related to taxes and bureaucracy is better rated in Macedonia, followed by Slovenia again. Overall satisfaction across other dimensions is weaker. In Croatia, there was an evident fall after 2013 in the overall satisfaction of this dimension, perhaps due to the failed expectations of improvement in these conditions following accession to the EU. This pattern is similar to the $R \& D$ transfer dimension that relates to the wider concept of knowledge transfer (i.e. science-industry collaboration). The rating of this dimension for both EU members (Slovenia and Croatia), and for Bosnia and Herzegovina, seems more closely related to external economic conditions than is the case for other dimensions. The world financial crisis of 2008/09 seems to have had a negative effect on the satisfaction of these conditions.

The WGI include perceptions of regulatory quality related to the quality of public policies and regulations, as well as their implementation in terms of how supportive they are of private sector development. Perceptions in the EU Member States are far better than in other countries, particularly so in Slovenia. Some effects of external conditions are evident in this dimension as well, as the most favourable perceptions are seen in 2009, with a worsening in the following period. An improvement in the perceptions of regulatory quality in Macedonia and Serbia was noticeable at the end of the period, in 2014 and 2015.

The rule of law is another WGI dimension. Perceptions capture the reliance of agents on the rule of law and on law enforcement. Slovenia is most advanced and stable in this respect, followed by Croatia, but with a much lower rating (but with some improvement throughout the period). Both Serbia and Bosnia and Herzegovina see an improvement in this dimension throughout the period. Finally, the WGI include control of corruption as a dimension that captures all types of corruption and misuse of public power for private interests. Again, Slovenia is best perceived across this dimension, while Croatia sees some improvement in the post-accession period.

\section{MODEL SPECIFICATION AND RESULTS}

In order to analyse the effects of different dimensions of institutional development on firm performance, firm-level data (micro-level variables) and various institutional development indicators (macro-level variables) were combined within a fixed-effect panel regression model. This approach allows control to be performed for variables that change over time but not across entities like national policies, regulations, tax and bureaucracy conditions, and also multi-level or hierarchical modeling which means combining multi-level data sources. Hsiao (2003) and Klevmarken (1989) list several benefits of using panel models which allow for controlling for individual heterogeneity, more variability, less collinearity among the variables, more degrees of freedom and more efficiency of the data. In addition, in panel models, the dynamics of adjustment can be better studied, and the effects that are simply not detectable in pure cross-section or pure time-series data can be better detected and measured.

A panel model can be presented in (1):

$$
y_{i, t}=\alpha+X_{i, t}^{\prime} \beta+u_{i, t} \quad i=1, \ldots, N ; t=1, \ldots T,
$$

where $i$ denotes the cross-section dimension (in our case $i$ denotes a specific firm), $t$ denotes the timeseries dimension (in our case it denotes years), $\alpha$ is a scalar (constant term), $\beta$ is the $\mathrm{K} \times 1$ vector of coefficients, $X_{i, t}$ is the $i, t^{\text {th }}$ observation on $K$ explanatory variables, and $u_{i, t}$ is the one-way error component. This error component $\left(u_{i, t}\right)$ consists of a time-invariant unobservable individual-specific effect that is not included in the regression $\left(\mu_{i}\right)$, and the remainder of the disturbance that varies within the cross-section and time-series dimension $\left(v_{i, t}\right)$ :

$$
u_{i, t}=\mu_{i}+v_{i, t}
$$

In the present case, accounts for any specific unobserved ability of a certain firm which is not included in the regression, such as the unobservable entrepreneurial or managerial skills of the firm's executives. The present model uses the augmented Cobb-Douglas production function utilising data on firms across time, so, generally speaking, $Y_{i, t}$ will measure output and $X_{i, t}$ will measure inputs augmented with variables that represent the institutional conditions.

In the current research, focus is placed on a specific set of $N$ firms in the industrial sector which are located in one of the following five countries (Bosnia and Herzegovina, Croatia, Macedonia, Serbia and Slovenia) and the inference is restricted to these countries. According to Baltagi (2008), under these conditions the fixed-effects (FE) model is an appropriate approach. The FE model relaxes the assumption that the regression function is constant over time and space and it allows each cross-sectional unit to have its own constant term while the slope estimates are constrained across units. The unit-specific intercept term absorbs all heterogeneity in $Y$ and $X$ (Baum 2006).

Another important assumption of the FE model is that time-invariant characteristics are unique to the individual and should not be correlated with other individual characteristics. Each entity is different, so the 
entity's error term and the constant (which captures individual characteristics) should not be correlated with the others. If the error terms are correlated, then the FE model is not suitable. The Cross-section $\mathrm{F}$ and Cross-section Chi-square tests with the null hypothesis that the cross-section effects are redundant are used to test if the FE model is an appropriate model specification.

We estimate a model where a conventional fixed effects estimator is used. Most of the regressed variables in the model have a lag of three years, and it is reasonable to assume that there is no endogeneity problem. The form of the model is:

$$
\operatorname{LNPROD}_{i, t}
$$

$$
\begin{aligned}
& =\alpha+\beta_{1} L N T F A+\beta_{2} L N L C O S T+\beta_{3} L N M C O S T \\
& +\beta_{4} C C+\beta_{5} T B+\beta_{6} R L+\beta_{7} R Q+\beta_{8} R D \\
& +\beta_{9} P S I+\beta_{10} C P I N F+\beta_{10+k} D U M_{-} Y R_{k}+\mu_{i} \\
& +v_{i, t}, \quad k=1, \ldots, 5
\end{aligned}
$$

where LNPROD denotes the log of labour productivity in industrial corporations. LNTFA, LNLCOST and LNMCOST are components of the production function and denote the log of tangible fixed assets and the labour cost and material cost, respectively. Furthermore, in the model we include these institutional variables, all with lag (3): CC - control of corruption, TB - taxes and bureaucracy, RL - rule of law, RQ - regulatory quality, RD - R\&D transfer, PSI - physical and services infrastructure, and CPINF - commercial and professional infrastructure. We use these variables with a lag in order to take into account the fact that the institutional conditions can influence the dependent variable only with a certain delay. In order to isolate time effects, we use five time dummy variables. The microeconomic data used in the model were obtained from Bureau van Dijk's Orbis database on firms, which allows for international comparison. In terms of selective variables, data on the quality of governance and institutional setting were used. As mentioned, these data were drawn from the Worldwide Governance Indicators issued by the World Bank and the Global Entrepreneurship Monitor survey (GEM). The institution data were shown with a shift of three years. In the model, it was assumed that changes in the institution in year $t$ influence the firms' performance in period $\mathrm{t}+3$.

In Olbrecht et al. (2016), the authors also use a multilevel approach and the WGI database, but, in contrast to Olbrecht et al. (2016), our paper exploits the chosen dimensions of the WGI index separately, and by using this approach it is possible to gain more precise insight into the influence of these institutional conditions, because one dimension can have a positive influence (control of corruption), while another can have a negative (regulatory quality) or no influence (rule of law). In the mentioned paper, the authors in their panel model found the WGI variable insignificant, and in the multilevel model, they found it positively significant.

Employing the module xtivreg2 of Stata software, in our model we clustered data in one cluster based on the criterion "country" and we used the "robust" option

\begin{tabular}{|c|c|}
\hline & Model \\
\hline Tangible fixed assests (LNTFA) & $\begin{array}{l}-0.00302 \\
(0.00777)\end{array}$ \\
\hline Labour cost (LNLCOST) & $\begin{array}{l}-0.2141^{* *} \\
(0.01395)\end{array}$ \\
\hline Material cost (LNMCOST) & $\begin{array}{l}0.3195^{* *} \\
(0.06254)\end{array}$ \\
\hline Control of corruptiom (lag3_CC) & $\begin{array}{c}0.87703^{* *} \\
(0.1052)\end{array}$ \\
\hline Taxes and bureaucracy (lag3_TB) & $\begin{array}{c}-0.05088^{* *} \\
(0.01097)\end{array}$ \\
\hline Rule of law (lag3_RL) & $\begin{array}{c}-0.3708 \\
(0.03124)\end{array}$ \\
\hline Regulatory quality (lag3_RQ) & $\begin{array}{c}-0.48566^{* *} \\
(0.13637)\end{array}$ \\
\hline $\begin{array}{l}\text { Research and development transfer } \\
\text { (lag3_RD) }\end{array}$ & $\begin{array}{c}-0.11455^{* *} \\
(0.02399)\end{array}$ \\
\hline $\begin{array}{l}\text { Psychical and service infrastructure } \\
\text { (lag3_PSI) }\end{array}$ & $\begin{array}{c}-0.02512^{* *} \\
(0.0053)\end{array}$ \\
\hline $\begin{array}{l}\text { Commercial and prof. infrastructure } \\
\text { (lag3_CPINF) }\end{array}$ & $\begin{array}{l}0.28611^{* *} \\
(0,05761)\end{array}$ \\
\hline DUM_YR1 & $\begin{array}{c}0.01247 \\
(0.00760)\end{array}$ \\
\hline DUM_YR2 & $\begin{array}{l}0.09828^{* *} \\
(0.01399)\end{array}$ \\
\hline DUM_YR3 & $\begin{array}{l}0.12248^{* *} \\
(0.01639) \\
\end{array}$ \\
\hline DUM_YR4 & $\begin{array}{l}0.08588^{* *} \\
(0.01222)\end{array}$ \\
\hline DUM_YR5 & $\begin{array}{l}0.01131 \\
(0.0075)\end{array}$ \\
\hline
\end{tabular}
to implement Eicker-Huber-White heteroskedastisticrobust standard errors. Table 2 shows the results of our model and Table 3 presents the standard diagnostics.

Table 2: Results of estimation

Notes: Robust standard errors are in parentheses, ** - denotes significance at the $1 \%$ level

Sources: Authors' calculation 
Table 3: Diagnostics

\begin{tabular}{|c|c|}
\hline & Model \\
\hline$F(15,4)$ & 76.81 \\
\hline Prob $>F$ & 0.0004 \\
\hline Centred R2 & 0.0846 \\
\hline Uncentred R2 & 0.0846 \\
\hline \multicolumn{2}{|l|}{ Hausman test: } \\
\hline \multicolumn{2}{|c|}{$\begin{array}{l}\text { Test: Ho: difference in coefficients not systematic } \\
\qquad \begin{aligned} \text { chi2 } 2(14)=(b-B)^{\prime}\left[\left(V_{-} \text {b-V_B }\right) \wedge(-1)\right](b-B) \\
=5870.34 \\
\text { Prob }>\text { chi } 2=0.0000 \\
\\
(\text { V_b-V_B is not positive definite })\end{aligned}\end{array}$} \\
\hline \multicolumn{2}{|c|}{ Test that all time dummies are equal to zero: } \\
\hline $\begin{array}{l}\text { ( 1) } y r 1=0 \\
\text { ( 2) } y r 2=0 \\
\text { (3) } y r 3=0 \\
\text { (4) } y r 4=0 \\
\text { (5) } y r 5=0 \\
\text { chi2 }(5)=38.23 \\
\text { Prob }>\text { chi2 }=0.0000\end{array}$ & \\
\hline
\end{tabular}

Sources: Authors' calculation.

The results are based on 129,556 observations.

We conducted the Hausman test in order to make a decision on whether to use fixed or random effects. The test results (Prob $>$ chi $2=0.0000<0.05$ ) suggest that the fixed effects model should be used on this dataset. Furthermore, we also tested if time dummy variables are necessary in our model. After running the tesparm command we obtained results (Prob $>$ chi $2=0.0000<0.05$ ) that strongly support rejecting the null hypothesis that the coefficients for all years are jointly equal to zero. Consequently, we include the time dummy variables. All test results are reported in Table 3.

The results of the model show that LNLCOST, LNMCOST, CC, TB, RL, RQ, RD, PSI and CPINF (with a lag of 3 years) are statistically significant variables, while LNTFA and RL are not. The negative sign of LNLCOST with the simultaneous positive sign of LNMCOST in both models shows the substitution of labour input with capital input in industrial production processes. The positive sign of CC and CPINF means that an improvement in this part of the institutional infrastructure can boost industrial production.

It is interesting that our research leads us to the negative signs of the $T B, R Q, R D$ and $P S I$ variables. The finding of the negative effect of a more efficient tax and bureaucratic system on labour productivity in industrial corporations can be explained. The introduction of a more efficient tax system leads to the expansion of the tax base. In this context, this increases the tax liabilities for certain companies, which generates upward pressure on prices (if they wish to maintain the achieved level of profitability) and reduces sales revenue. If companies do not respond to this by adjusting the labour force, the result is lower productivity.

A better quality of the regulatory framework requires companies to increase the engagement of additional resources to meet regulatory standards. At the same time, it limits market power, which leads to a decline in sales revenue. If companies do not respond to this through adjustments on the labour side, a decrease in productivity can be expected.

We also find the negative impact of the R\&D infrastructure. For this finding, two explanations can be offered. On the one hand, transition countries are well known as centres of labour and resource intensive activities within the global value-added chain. In this context, the allocation of resources to $R \& D$ activities draws resources from optimal usage according to the comparative advantages of these countries. On the other hand, it is possible that there is a lack of absorption capacity of the enterprise to exploit R\&D capacity. Both explanations point to the need for economic policy measures to increase the company's absorption capacity and that will lead to its better positioning in the global added value chain.

The negative finding of the impact of the physical infrastructure on enterprise productivity can be explained by the absence of complementarity between the absorption capacity of the enterprise and the available infrastructure. The inability of companies to optimally exploit the existing infrastructure leads to a drop in efficiency.

We can partially compare our results with the research of Goedhuys and Srholec (2015). These authors investigate the impact of national institutions on the total factor productivity of firms by using a data set of manufacturing firms in 32 developing countries. They measure the macro indicators with a five-year lag respective to the micro data and they organise variables employing a principal component factor method of extraction and the orthogonal varimax rotation procedure. In total, four variables are organised: political system organisation (POL), quality of governance (GAV), educational indicators (EDU), and quality of research infrastructure (TECH). GAV includes political stability, rule of law and control of corruption, and TECH includes R\&D expenditure. Our finding of the negative lag3_RD coefficient is consistent with Goedhuys and Srholec who found that in some countries the return on business R\&D is negative. Furthermore, our results of the lag3_CC and lag3_RQ coefficients are in line with their conclusion that GOV does not make much difference for the intercept or for cross-level interaction. 


\section{CONCLUSION}

CESEE countries experienced transition from a planned economy to a market economy that was accompanied by a collapse of existing markets and the need to restructure dominant firms in their national markets. This complex set of unfavourable conditions made the institutional changes in these countries quite challenging. Two tasks were set before these countries in terms of their institutional development: the first was the building of market-oriented institutions, and the second was increasing the efficiency of institutions to match EU standards. Both tasks were of critical importance: the first was economic, in terms of the influence of institutions on firm performance in these countries, and the second was political, in terms of the CESEE countries approaching the EU. The latter aspect can ultimately be seen to be the driving force behind institutional change. On a policy level, institutional change has risen in importance over the last two decades in CESEE countries.

As a result of the institutional dynamics driven by a strong political agenda, the CESEE countries which have become EU Member States have benefited from strong institutional change and performance compared to the CESEE countries that are still outside the $\mathrm{EU}$, which is reflected in firm performance. This proposition has relevance for the interpretation of the empirical findings arising from this research. In this paper, our analysis has focused on two EU Member States (Slovenia and Croatia) and on other CESEE countries (Serbia, Macedonia and Bosnia and Herzegovina) that are approaching the EU. Among the analysed countries, the overall conditions are most satisfactory in Slovenia, the first country to join the EU among the countries under review. Being an EU Member State and adopting EU norms could explain why regulatory quality, one of the World Governance Index (WGI) dimensions, is better observed among the EU Member States of Slovenia and Croatia than the other countries. These findings are similar to the finding related to the rule of law, another WGI dimension, where Slovenia is the leading country, followed again by Croatia. "Institutional convergence" through EU membership is not a guarantee of sufficiently strong institutional change and reform across all institutional dimensions, as the Croatian case shows. Croatia, which became an EU Member State in 2013, experienced failed expectations in two dimensions of the analysed indicators - taxes and bureaucracy and R\&D transfer in the analysed period from 2010 to 2015. Furthermore, Croatia is, for example, lagging behind the non-EU country Macedonia across the indicators taxes and bureaucracy and commercial and professional infrastructure.

Employing the econometric model confirmed the effects of the institutional variables with a certain lag of time on firm performance. The results show that the variables control of corruption and commercial and professional infrastructure were positively significant, implying that it is these basic conditions that could, with further improvement, be the factors to boost industrial production in the selected countries. At the same time, the variables R\&D transfer, physical and service infrastructure, taxes and bureaucracy and regulatory quality appear significant, but with a negative sign in the model. The negative relation between science-industry collaboration and firm performance is perhaps not as surprising or counter-intuitive, as most of the economies in the sample are driven by improvements in efficiency in contrast to economies driven by innovation. Furthermore, improvements in other variables that were found significant may require devoting a part of company resources to keeping up with a more advanced but also more complex environment rather than productive activities. Adjustments in company resources are needed and this process may prove more difficult in CESEE countries than in their EU counterparts. In other words, there is a lack of absorptive capacities among firms in the analysed countries. Another important finding in the model is the negative sign of labour costs, with the simultaneously positive sign of material costs, implying the substitution of labour with capital input.

The limitations of this research lie in the fact not all CESEE countries, such as Montenegro, Albania, Bulgaria or Romania, could be included, which can be explained by the unavailability of their institutional data. Our approach to set up an econometric model with lagged variables, although with a strong theoretical background, further reduces the number of observations. In addition, we ignore informal institutions in this paper.

For future research, it would be useful to separately analyse the influence of institutions on firm performance in the analysed countries and then to compare this with the findings of the current paper. In this way, the influence of the specific type of institutions specified in the econometric model on firm performance could be more precisely measured.

The main policy implication of the research would be that it is necessary to know in detail the different types of institutions in order to recognise the appropriate policy instruments which may stimulate productivity in manufacturing. Some policy recommendations can be drawn based on the results shown in this paper. Through control of corruption, the presence of property rights, the availability of complex professional services and the presence SME-supporting institutions, policies can positively influence the 
performance of manufacturing firms.

The negative effect of R\&D transfer could be explained by the lack of capacity among companies that might transform R\&D activities into innovation. Therefore, policy effects should provide policy instruments that promote demand for innovative products and services (e.g. improvement in terms of standards and regulation) (Edler, Fagerberg, 2017). The desired effect of these actions would be to support more strongly transition to an innovation-driven economic model.

\section{REFERENCES}

Abramovitz, M. 1986. Catching up, forging ahead and falling behind. Journal of Economic History 46 (2), The Tasks of Economic History (June): 385-406.

Acemoglu, D., Gallego, F. A., Robinson, J. A. 2014. Institutions, human capital, and development. Annual Reviews of Economica 6 (1): 875-912.

Aghion, P., Howitt, P. 1992. A model of growth through creative destruction. Econometrica 60 (2): 323-351.

Archibugi, D., Denni, M., Filippetti, A. 2009. The technological capabilities of nations: The state of the art of synthetic indicators. Technological Forecasting \& Social Change 76 (7): 917-931.

Atieno, R. 2001. Formal and informal institutions> lending policies and access to credit by small-scale enterprises in Kenya: An empirical assessment. AERC Research Paper 111

African Economic Research Consortium, Nairobi November, $\quad$ https://www.africaportal.org/documents/5926/RP111.pdf (accessed 2 March 2018)

Baltagi, B. 2008. Econometric analysis of panel data. Chichester: John Wiley \& Sons.

Bartlett, W., Čučković, N., Krešimir, J., Nojkovič, A. 2013. Institutional quality and growth in EU neighbourhood countries. WP05/11 Search working paper. http://www. ub.edu/searchproject/wp-content/uploads/2013/01/ WP-5.11.pdf (accessed 2 March 2018)

Baum, C. F. 2006. An introduction to modern econometrics using Stata. College Station, TX: Stata press.

Beck, T., Laeven, L. 2006. Institution building and growth in transition economies. Journal of Economic Growth 11 (2): 157-186.

BvD - Bureau van Dijk 2017. Orbis, brochure. https://www. bvdinfo.com/en-gb/our products/data/international/ orbis?gclid=EAlalQobChMI dWOhNTD1wIVC7gbCh3ScgWhEAAYASAAEgKcHvD BwE (accessed September 15, 2017)

Commander, S., Svejnar, J., 2011. Business environment, exports, ownership and firm performance. Review of Economics and Statistics 93 (1): 309-337.
Crafts, N. 2001. Historical perspectives on development. In Frontiers of development economics: The future in perspective, edited by G. Meier, J. Stiglitz, 301-340. New York: Oxford University Press.

Dang, V. 2009. Institutional determinants of investment in transition economies. Economics and Finance Working Paper Series No. 09-33. Brunel University West London. https://pdfs.semanticscholar.org/e03e/96fa9c61cc160b 765afcac49f9036f4ddca3.pdf

Dias, J., Tebaldi, E. 2012. Institutions, human capital, and growth: The institutional mechanism. Structural Change and Economic Dynamics 23 (3): 300-312.

Dollar, D., Kraay, A. 2003. Institutions, trade, and growth. Journal of monetary economics 50 (1): 133-162.

EIS 2017. - European Innovation Scoreboard 2017, European Commission, http://ec.europa.eu/DocsRoom/documents/24829 (accessed October 22, 2017)

Edler, J., Fagerberg, J. 2017. Innovation policy: What, why, and how. Oxford Review of Economic Policy 33 (1): 2-23.

Efendic, A., Pugh, J. 2015. Institutional effects on economic performance in post socialist transition: A dynamic panel analysis. Acta Oeconomica 65 (4): 503-523.

Efendic, A., Mickiewicz, T., Rebmann, A. 2015. Growth aspirations and social capital: Young firms in post conflict environment. International Small Business Journal 33 (5): 537-561.

Estrin, S., Korosteleva, J., Mickiewicz, T. 2013. Which institutions encourage entrepreneurial growth aspirations? Journal of Business Venturing 28 (4): 564-580.

Estrin, S., Mickiewicz, T. 2011. Entrepreneurship in transition economies: The role of institutions and generational changes. In: The dynamics of entrepreneurship: Evidence from global entrepreneurship monitor data, edited by M. Minniti, 181-208. Oxford, Publisher?

Fagerberg, J. 1987. A technology growth approach, to why growth rates differ. Research policy 16 (2-4): 87-99.

Global Entrepreneurship Monitor (GEM) (2017): World Report 2016/17. http://www.gemconsortium.org/report/49812 (accessed November 10, 2017)

Global Entrepreneurship Monitor data. 2017. http:// www.gemconsortium.org/data/sets\#bnes (accessed November 15, 2017)

Goedhuys, M., Srholec, M. 2015. Technological capabilities, institutions and firm productivity: A multilevel study. European Journal of Development Research 27 (1): 122-139.

Hsiao, C. 2003. Analysis of panel data. Cambridge:Cambridge University Press.

Hu, A. G., Jefferson, G. H., Jinchang, Q. 2005. R\&D and technology transfer: Firm-level evidence from Chinese industry. Review of Economics and Statistics 87(4): 780-786.

Kaufmann, D., A. Kraay, M. Mastruzzi. 2010. Worldwide Governance Indicators methodology and analytical issues. Policy Research Working Paper 5430. World 
Bank, September. http://siteresources.worldbank.org/ INTMACRO/Resources/WPS5430.pdf (accessed October 10, 2017)

Klevmarken, N. A. 1989. Panel studies: What can we learn from them? Introduction. European Economic Review 33: 523-529. https://doi.org/10.1016/0014-2921(89)90131-1 (accessed 22 October 2017)

Lanjouw, J. O., Levy, P. I. 2002. Untitled: A study of formal and informal property rights in urban Ecuador. The Economic Journal 112 (482): 986-1019.

Mair, M. Marti, I. 2009. Entrepreneurship in and around institutional voids: A case study from Bangladesh. Journal of Business Venturing 24: 419-435.

Meyer, K. E., Peng, M. W. 2016. Theoretical foundations of emerging economy business research. Journal of International Business Studies 47 (1): 3-22.

Miščević, T., Mrak, M., 2017. The EU Accession process: Western Balkans vs EU-10. Croatian Political Science Review 54 (4): 185-204.

Mitra, P., Muravyev, A., Schaffer, M. E. 2008. Convergence in institutions and market outcomes: Cross-Country and time-series evidence from the BEEPS surveys in transition economies. IZA DP No. 3863. http://ftp.iza.org/ dp3863.pdf (accessed October 11, 2017)

Mohnen, P., Mairesse, J., Dagenais, M. 2006. Innovativity: A comparison across seven European countries. Economics of Innovation and New Technology 15 (4-5): 391-413.

Monteiro, J. C., Assunção, J. J. 2012. Coming out of the shadows? Estimating the impact of bureaucracy simplification and tax cut on formality in Brazilian microenterprises. Journal of Development Economics 99 (1): 105-115.

Nakabashi, L., Gonçalves Pereira, E. A., Sachsida, A. 2013. Institutions and growth: a developing country case study. Journal of Economic Studies, 40 (5): 614-634.

Ngo, V., D., Jansen, F., Leonidou, L., C., Christodoulides, P. 2016. Domestic institutional attributes as drivers of export performance in an emerging and transition economy. Journal of Business Research 69: 2911-2922.

Nguyen, T. V., Le, N .T. B. , Bryant, S. E. 2013. Sub-national institutions, firm strategies, and firm performance: A multilevel study of private manufacturing firms in Vietnam. Journal of World Business 48 (1): 68-76.

North, D. 1990. Institutions, institutional change and economic performance. Cambridge: Cambridge University Press.

Olbrecht, V. 2016. Multilevel modeling in exploring institutional effects on performance. Acta Universitatis Agriculturae et Silviculturae Mendelianae Brunensis 64 (6): 2087-2094.

Raiser, M. 1999. Trust in transition. Postcommunist transformation and the social sciences: cross disciplinary approaches. Conference proceedings, Berlin.
Redek, T., Sušjan, A. 2005. The impacts of institutions on economic growth: The case of transition economies. Journal of Economic Issues 39(4): 995-1027.

Rodrik, D., Subramanian, A., Trebbi, F. 2004. Institutions rule: The primacy of institutions over geography and integration in economic development. Journal of Economic Growth 9(2): 131-165.

Romer, P. M. 1986. Increasing returns and long-run growth. Journal of Political Economy 94 (5): 1002-1037.

Talbott, J., Roll, R. 2001. Why many developing countries just aren't. Anderson School UCLA, Finance Working Paper No. 19-01. https://papers.ssrn.com/sol3/papers. cfm?abstract id=292140 (accessed 22 October 2017)

Temple, J., Johnson, P. A. 1998. Social capability and economic growth. The Quarterly Journal of Economics 113 (3): 965-990.

Verspagen, B. 1991. A new empirical research to catching up or falling behind. Structural Change and Economic Dynamic 2 (2): 359-380.

Vijayaraghavan M., Ward, W. A. 2001. Institutions and economic growth: Empirical evidence from a cross-national analysis. Center for International Trade, Working Paper 001302. http://ageconsearch.umn.edu/bitstream/112952/2/citpaper11.pdf (accessed 25 October 2017)

WB - World Bank, 2017. Worldwide Governance Indicators. http://info.worldbank.org/governance/wgi/index. aspx\#home. (accessed November 15, 2017)

Williams, C., C., Franic, J. 2016. Explaining participation in the informal economy in post-socialist societies: A study of the asymmetry between formal and informal institutions in Croatia. Journal of Contemporary Central and Eastern Europe 24 (1): 51-65.

Williams, C. C. Shahid, M. S. 2016. Informal entrepreneurship and institutional theory: Explaining the varying degrees of (in)formalization of entrepreneurs in Pakistan. Entrepreneurship \& Regional Development, 28 (1-2): 1-25.

Williams, N., Vorley, T. 2015. Institutional asymmetry: How formal and informal institutions affect entrepreneurship in Bulgaria. International Small Business Journal, 33 (8): 840-861.

Williams, N., Vorley, T. 2017. Fostering productive entrepreneurship in post-conflict economies: The importance of institutional alignment. Entrepreneurship \& Regional Development, 29 (5-6): 444-466. DOI: 10.1080/08985626.2017.1297853 (accessed 22 October 2017).

Zamberi Ahmad, S, Xavier, S.R. 2012. Entrepreneurial environments and growth: Evidence from Malaysia GEM data. Journal of Chinese Entrepreneurship 4 (1): 50 69. https://doi.org/10.1108/17561391211200939 (accessed October 22, 2017) 


\section{Acknowledgment}

This work was fully supported by the Croatian Science Foundation under project IP-2016-06-3764.

\section{(Endnotes)}

1 Government intervention in market mechanisms is justified only if it is geared towards fixing situations in which markets fail to efficiently allocate resources (Arrow 1951).

2 As Archibugi, Denni, and Filippetti (2009, p 920) explain, this group of indicators represent the current endowment of countries to base their current and future competitiveness and growth on the creation, use and diffusion of technological innovation.

3 These capabilities are technical competence, experience in the organisation and management of large-scale enterprises, financial institutions and markets capable of mobilising large amounts of capital, honesty and trust and the stability of government and its effectiveness in defining rules and supporting economic growth.

4 In this context, the implementation of market reforms with a focus on the development of entrepreneurship might lead to the advancement of formal institutions whereas non-formal institutions remain unsupportive.

5 Entrepreneurs' employment growth aspiration was defined as a percentage change in the expected level of employment in five years with respect to the current level of employment by young businesses. 